\title{
ИЗУЧЕНИЕ ФУНКЦИОНАЛЬНО-ТЕХНОЛОГИЧЕСКИХ СВОЙСТВ БЕЛКОВО-ВИТАМИННЫХ И БЕЛКОВО-УГЛЕВОДНЫХ ДОБАВОК НА ОСНОВЕ СОИ
}

\section{O.V. Skripko}

\section{THE STUDY OF FUNCTIONAL AND TECHNOLOGICAL PROPERTIES OF PROTEINACEOUS AND VITAMIN AND PROTEINACEOUS CARBOHYDRATE ADDITIVES ON THE BASIS OF SOY}

Скрипко Ольга Валерьевна - д-р техн. наук, доц., проф., зав. каф. автоматизации производственных процессов и электротехники Амурского государственного университета, г. Благовещенск. E-mail: oskripko18@mail.ru

Цель исследования - изучение функционально-технологических свойств разработанных в ФГБНУ ВНИИ сои инновационных пищевых добавок в виде белково-витаминных концентратов (БВК) и белково-углеводных гранулятов (БУГ). Задачи исследования: определить растворимость в воде БВК в виде гранул и муки, а также БУГ в гранулированном виде; установить продолжительность набухания муки и гранул БУГ и БВК; определить водосвязывающую (ВCC) и водопоглотительную (ВПС) способность БВК и БУГ в гранулированном и диспергированном виде. В результате исследования изучены основные фуункциональнотехнологические свойства: растворимость, набухаемость, водопоглотительная способность и водосвязывающая способность добавок в виде гранул и в диспергированном виде. Установлено, что растворимость и набухаемость добавок зависит, прежде всего, от химического состава компонента, а также от его фризической формы. Так, белково-вита-минные концентраты обладают более высокой набухаемостью, но процесс набухания протекает медленно в сравнении с белково-углеводными гранулятами. Водопоглотительная способность добавок в виде муки на 23-32 \% выше, чем водопоглотительная способность добавок в виде гранул, что связано с фризической формой добавки и площадью соприкосновения материала с водой. Установлено, что данный вид добавок обладает высокой водосвязывающей способностью от 183 \% для гранул белково-
Skripko Olga Valeryevna - Dr. Techn. Sci., Assoc. Prof., Prof., Head, Chair of Productions and Electrical Equipment Automation, Amur State University, Blagoveshchensk.

E-mail: oskripko18@mail.ru

витаминного концентрата до 304 \% муки из белково-углеводного гранулята, при этом водосвязывающая способность добавок в виде муки значительно превосходит водосвязьвающую способность добавок в виде гранул. Результаты исследований фуннкциональнотехнологических свойств белково-витаминных и белково-углеводных добавок позволили определить возможности их дальнейшего использования для повышения пищевой и биологической ценности инновационных продуктов питания.

Ключевые слова: белково-витаминные концентраты, белково-углеводнье грануляты, функционально-технологические свойства.

The purpose of the researches was studying at FSBSI 'All-Russian Scientific Research Institute of Soybean' functional and technological properties of innovative food additives developed in the form of proteinaceous and vitamin concentrates (PVC) and proteinaceous and carbohydrate granulates (PCG). The research problems were to define the solubility in PVC water in the form of granules and torments, and also PCG in the granulated kind; to establish the duration of swelling of the flour and granules PCG and PVC; to define water connecting (WCA) and water absorbing (WAA) ability of PVC and PCG in granulated and dispersed kind. As a result of the researches the main functional and technological properties were studied: solubility, swelling capacity, water absorbing ability and water connecting ability of additives in the form of granules and in dispersed form. It was established that solubility and swelling 
capacity of additives depended first of all, on chemical composition of the component, and also on its physical form. So, proteinaceous and vitamin concentrates possess higher swelling capacity, but process of swelling proceeds slowly in comparison with proteinaceous and carbohydrate granulates. Water absorbing ability of additives in the form of the flour is $23-32 \%$ higher, than water absorbing ability of additives in the form of granules that is connected with a physical form of an additive and the area of contact of material with water. It was established that this type of additives possessed high water connecting ability from $183 \%$ for granules of proteinaceous and vitamin concentrate to $304 \%$ of the flour from proteinaceous and carbohydrate granulate, thus water connecting ability of additives in the form of a flour considerably surpasses the water connecting ability of additives in the form of granules. The results of the researches of functional and technologi$\mathrm{cal}$ properties of proteinaceous and vitamin and proteinaceous and carbohydrate additives allowed to define possibilities of their further use for increase of nutrition and biological value of innovative food products.

Keywords: protein and vitamin concentrates, protein and carbohydrate granulates, functional and technological properties.

Введение. Получение продуктов питания функционального и специализированного назначения сегодня обеспечивается, прежде всего, введением в состав традиционных пищевых продуктов различных добавок, обогащающих продукты теми или иными веществами и обладающих корригирующим действием на организм человека. Вместе с тем при обогащении пищевых продуктов различными добавками необходимо учитывать как улучшение их химического состава и повышение пищевой ценности, так и совместимость их с другими компонентами рецептуры, не снижающую их качества. Поэтому возникает необходимость тщательного выбора формы, способов и стадий внесения добавок, их взаимное дополнение, обогащение и сочетание, которые будут способствовать максимальному достижению требуемых функциональных и потребительских свойств [1, 2].

Проведенное нами исследование позволило разработать безотходные технологии получения добавок корригирующего действия для функ- циональных продуктов питания из сои и овощей (моркови, сладкого перца, свеклы, тыквы), сои и морских водорослей (ламинарии), сои и лесных грибов, сои и папоротника Орляк путем извлечения белка из подготовленного сырья без потерь ценных компонентов, с использованием в качестве коагулянтов растворов органических кислот и биологически активных добавок к пище $[3,4]$. Нами получены добавки в виде белкововитаминных концентратов (БВК) и белковоуглеводных гранулятов (БУГ). Внесение этих добавок в рецептуры пищевых концентратов (супов и каш, крупяных пудингов, смесей для выпечки, картофрельного пюре и лапши быстрого приготовления, соусов и др.), хлеба, мучных кондитерских изделий, мясных и рыбных рубленых изделий позволяет обогатить химический состав физиологически ценными питательными веществами - белками, витаминами $\mathrm{E}$ и С, а также пищевыми волокнами.

Полученные по разработанным технологиям белково-витаминные концентраты и белковоуглеводные грануляты представляют собой пористые, хрупкие, в меру ломкие гранулы с шероховатой поверхностью, различной цветовой гаммы (в зависимости от вида используемого сырья), с умеренно выраженным, приятным вкусом и запахом входящих в состав компонентов.

Белково-витаминные концентраты содержат в своем составе от 25 до 43 г белка; 6,5-17,0 г жира; 100-150 мг витамина C и 8,0-10 мг витамина Е в 100 г, белково-углеводные грануляты содержат до 32 г пищевых волокон, что составляет суточную норму потребления данных веществ для взрослого человека, на 100 г продукта, причем в их составе присутствуют также белки, витамин Е и минеральные вещества $[3,4]$.

БВК и БУГ являются ценными пищевыми добавками и могут использоваться для обогащения пищевых продуктов белком, растительными жирами, пищевыми волокнами, витаминами и минеральными веществами и могут быть использованы для коррекции пищевого статуса населения РФ.

Вместе с тем, необходимо учитывать, что процесс приготовления обогащенных продуктов питания в значительной степени зависит от функционально-технологических свойств (ФТС) исходного сырья и компонентов рецептуры. Поэтому при проектировании продуктов питания с исполь- 
зованием новых видов добавок в гранулированном и диспергированном виде необходимо изучить их ФТС, а также возможности влияния ФТС на формирование структуры продуктов и способы технологической обработки $[5,6]$.

Цель исследования: изучение функционально-технологических свойств белково-витаминных концентратов и белково-углеводных гранулятов для использования их в рецептурах обогащенных пищевых продуктов.

Задачи исследования: определить растворимость в воде БВК в виде гранул и муки, а также БУГ в гранулированном виде; установить продолжительность набухания муки и гранул БУГ и БВК; определить водосвязывающую (ВСС) и водопоглотительную (ВПС) способность БВК и БУГ в гранулированном и диспергированном виде.

Объекты исследования. Объектами исследования являлись белково-витаминные концентраты и белково-углеводные грануляты семи наименований, полученные по разработанной авторами технологии и соответствующие требованиям ТУ 9199-001-00668442-11 «Соевоперцевый концентрат», ТУ 9199-002-0066844211 «Соево-перцевый гранулят», ТУ 9197-00100668442-12 «Белково-витаминный концентрат (морковный)», ТУ 9197-002-00668442-12 «Белково-углеводный гранулят (морковный)», ТУ 9197-001-00668442-13 «Белково-витаминный концентрат (соево-свекольный, соево-тыквенный)», ТУ 9197-002-00668442-13 «Белковоуглеводный гранулят (соево-свекольный, соевотыквенный)», ТУ 9197-001-00668442-14 «Белково-витаминный концентрат (соево-ламинариевый)», ТУ 9197-002-00668442-14 «Белкововитаминный гранулят (соево-ламинариевый)», СТО 9197-003-00668442-2015 «Белково-витаминный концентрат (соево-грибной)», СТО 9197-00400668442-2015 «Белково-углеводный гранулят (соево-грибной)», СТО 9197-003-00668442-2016 «Белково-витаминно-минеральный концентрат (соево-папоротниковый», СТО 9197-004-0066 8442-2016 «Белково-углеводный гранулят (соево-папоротниковый)».

Исследование проводилось в трехкратной повторности для каждого из семи наименований БВК и БУГ. Результаты исследования обобщены и представлены для четырех групп добавок: белково-витаминные концентраты в виде гранул; гранулы БВК, измельченные в муку; белко- во-углеводные грануляты в виде гранул; гранулы БУГ, измельченные в муку. В качестве результатов приведены средние значения, полученные в опытах.

Результаты исследования и их обсуждение. Количество и форма, в которой БВК или БУГ вносят в рецептуру продукта, зависит, прежде всего, от наименования пищевого продукта или изделия. При введении БВК или БУГ в состав пищевых концентратов первых и вторых обеденных блюд, пищевых концентратов быстрого приготовления, мясных или рыбных рубленых изделий или полуфабрикатов их используют в гранулированном виде. В процессе кулинарной обработки они набухают, но не растворяются, хорошо сохраняют форму, по внешнему виду напоминают мясной или рыбный фарш. При этом использование в данных изделиях добавок в виде муки может привести к загущению смеси, появлению мутности бульона и другим негативным проявлениям.

Вместе с тем, для соусов, мучных кондитерских изделий, смесей для выпечки приоритетным является использование добавок в диспергированном виде (в виде муки или порошка), так как гранулированные БВК и БУГ не позволяют достичь требуемых структурно-механических характеристик. При регидратации и приготовлении они не разрушаются, тем самым плохо влияют на вязкость и текучесть, намокаемость и смешиваемость, достижение однородности смесей.

При разработке рецептур указанных изделий необходимо учитывать функционально-технологические свойства полученных добавок.

Дегидратированные добавки в процессе технологической обработки способны связывать и удерживать влагу, сгущать пищевые массы. Данную способность характеризуют такие фуннкционально-технологические свойства, как растворимость, набухаемость, водопоглотительная и водосвязывающая способность [5-7].

Высокая растворимость в воде белков, входящих в состав БВК и БУГ, способствует образованию прочных гелей, эластичных масс и стабильных эмульсий. Определение растворимости пищевых добавок в воде при температуре 18-20 ${ }^{\circ} \mathrm{C}$ проводили на образцах БВК в виде гранул и в дезинтегрированном виде (мука) и БУГ в виде гранул. Результаты исследований показаны на рисунке 1. 


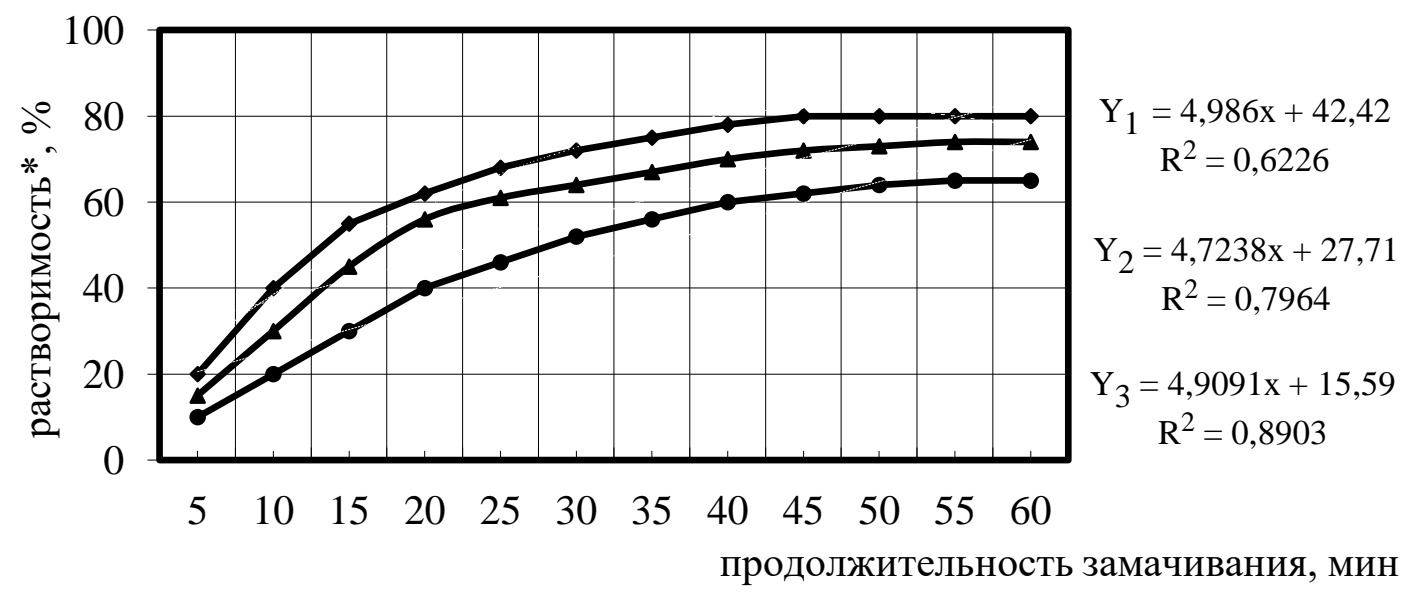

$\longrightarrow$ добавка в виде муки
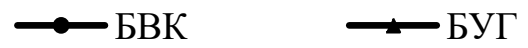

Puc. 1. Динамика растворимости добавок ( ${ }^{*}$ средние значения):

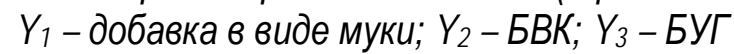

Исследованиями установлено, что наибольшей растворимостью (до 80 \%) обладают добавки в виде муки, при этом добавки в виде БВК обладают наименьшей растворимостью (до $65 \%$ ) в сравнении с БУГ (до 74 \%), что объясняется, прежде всего, химическим составом добавок, а также степенью диспергирования частиц. Высокое содержание частично денатурированных белковых веществ, содержание нерастворимых пищевых волокон значительно снижают растворимость БВК и БУГ.

Химический состав белково-витаминных концентратов характеризуется высоким содержанием белка, а белково-углеводных гранулятов - пищевых волокон. И белки и пищевые волокна обладают способностью образовывать ассоциативные связи с водой, следовательно, хорошо удерживают влагу, т. е. обладают повышенной гидрофиильностью. При этом процесс набухания зависит прежде всего от вида сырья и степени его измельчения, а также от температуры, вида и концентрации растворителя и т. д. [7].

Известно, что ингредиенты из сои в высушенном виде обладают высокой гидрофильностью и способны значительно набухать в воде. Данное свойство может существенно влиять на ход технологического процесса. Поэтому важно исследовать динамику набухания с учетом временного фрактора для белково-витаминного кон- центрата в виде муки и гранул, а также белковоуглеводного гранулята в гранулированном виде.

Набухаемость характеризуется максимальным количеством воды, которое исследуемый объект может поглотить и удержать до наступления динамического равновесия, отнесенным к массе навески. Исследование проводили объемным методом [6]. В результате исследования установлено, что продолжительность набухания муки из белково-витаминного концентрата составляет 20 мин, гранул белково-углеводного гранулята - 25 мин, а белково-витаминного концентрата в виде гранул - 35 мин, что можно объяснить различными размерами частиц компонентов. Различное время набухания гранул БУГ и БВК связано с более быстрым поглощением воды пищевыми волокнами, содержащимися в БУГ. При этом процесс набухаемости БВК протекает медленнее, но белковые вещества, содержание которых в БВК выше, чем в БУГ, поглощают больше влаги, за счет чего количество воды, которое впитывают гранулы, увеличивается. Высокая набухаемость добавок обусловливает повышение вязкости их водных суспензий.

Для определения водопоглотительной способности БВК и БУГ пробу помещали в пробирку, туда же вносили дистиллированную воду, смесь перемешивали и для набухания белков оставляли 
на 15 мин. После чего пробирку помещали в центрифугу, по окончании центрифугирования надосадочный раствор сливали и измеряли количество воды, связанное белками [5].

На рисунке 2 представлены результаты исследований по определению водопоглотительной способности, которые свидетельствуют о том, что белково-витаминные и белково-углеводные концентраты обладают высокими показателями водопоглотительной способности.

Добавки БВК и БУГ в виде муки поглощают воды 332 и $348 \%$ соответственно, а БВК и БУГ в виде гранул - 309 и $318 \%$. Поученные результаты объясняются тем, что добавки в виде муки имеют большую площадь соприкосновения с водой в отличие от добавок в виде гранул. Вместе с тем, результаты исследований позволяют охарактеризовать оба вида добавок как перспективный водопоглотительный компонент.

Водосвязывающая способность характеризуется как свойство белковых продуктов абсорбировать и удерживать воду за счет присутствия в них гидрофрильных групп [5]. Эта способность является важным технологическим фрактором для белко- вых добавок, так как позволяет прогнозировать водоудерживающие и реологические характеристики продуктов на этапе их проектирования. Данные характеристики, в свою очередь, обеспечивают консистенцию готовых продуктов, оказывают влияние на выход продукта и потери сырья при технологической обработке.

Эксперимент по установлению водосвязывающей способности добавок проводили путем настаивания и центрифугирования водной суспензии, с определением количества воды, которое добавки адсорбировали и удерживали.

Результаты исследований представлены на рисунке 3.

БВК и БУГ обладают высокой ВСС, так, добавки БВК и БУГ в виде муки связывают 285 и $304 \%$ воды соответственно, а БВК и БУГ в виде гранул - 183 и 202 \%. Высокая ВСС концентратов и гранулятов обусловлена значительным содержанием в них белка, способного к гидратации и набуханию. Результаты исследований позволяют определить возможность их использования в качестве водоудерживающих ингредиентов в рецептурах пищевых продуктов.

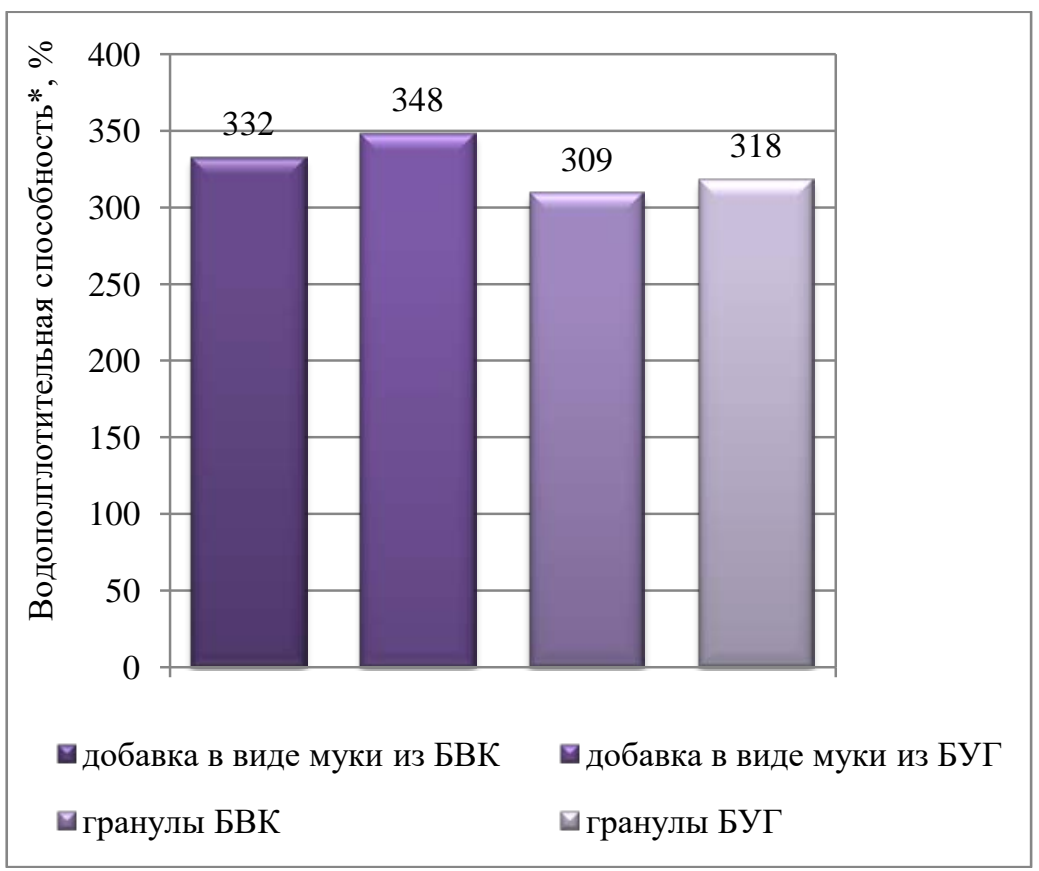

Puc. 2. Водопоглотительная способность добавок (" 


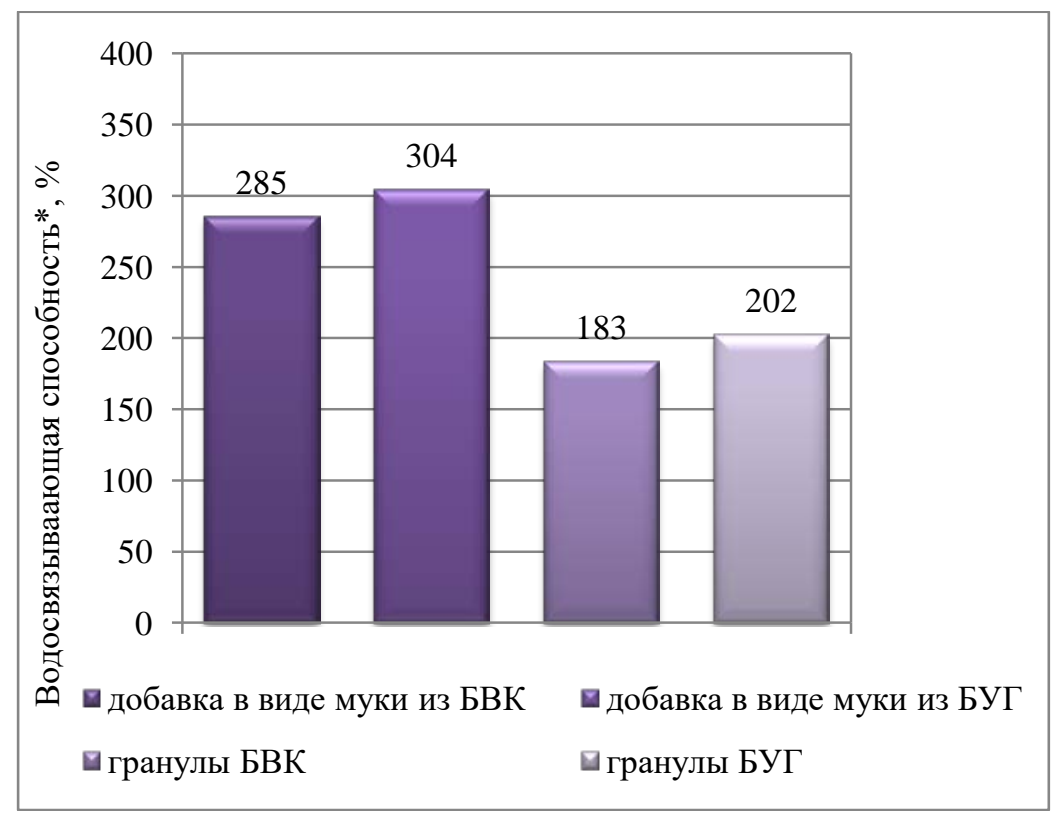

Puc. 3. Водосвязывающая способность добавок ("средние значения)

Выводы. Таким образом, исследованиями ФТС белково-витаминных концентратов и белково-углеводных гранулятов установлено, что добавки в диспергированном виде (в форме муки или порошка) характеризуются лучшими функционально-технологическим свойствами, обладают большей растворимостью (до $80 \%$ относительно $65 \%$ для БВК в гранулированном виде), набухаемостью (в течение 20 мин против 25 мин для БУГ и 35 мин для БВК в виде гранул). ВПС добавок в виде муки на 23-32 \% выше, чем водопоглотительная способность добавок в виде гранул, а ВСС составляет от $183 \%$ для гранул БВК до 304 \% муки из БУГ. Добавки в такой форме будут иметь преимущество при использовании в рецептурах пищевых продуктов, если такая форма не будет способствовать снижению (ухудшению) потребительских свойств готового пищевого продукта, например придавать мутность бульону, способствовать клейстеризации смеси и т. д. Добавки в гранулированном виде также характеризуются высокими функционально-технологическими свойствами и могут успешно применяться в рецептурах пищевых продуктов, в состав которых входит крупноизмельченное сырье (крупы, овощи, мясо, рыба, фрарш и др.).

\section{Литература}

1. Доронин А.Ф., Демидова Т.И., Шеверницкая О.Н. и др. Функциональные комбинированные порошковые продукты // Хранение и переработка сельхозсырья. 2010. № 5. C. 45-48.

2. Спиричев В.Б., Шатнюк Л.Н., Позняковский В.М. Обогащение пищевых продуктов витаминами и минеральными веществами. Наука и технологии. Новосибирск, 2004. 548 c.

3. Скрипко О.В., Литвиненко О.В., Покотило О.B. Обоснование технологии и оценка качества соево-грибных продуктов для функционального питания // Техника и технология пищевых производств. 2016. № 3 (42). C. 77-83.

4. Скрипко О.В., Литвиненко О.В., Покотило О.В. Разработка технологии функциональных продуктов питания на основе сои и папоротника // Вестник КрасГАУ. 2017. № 6. C. 96-103.

5. Ольховая Л.П., Петрова Л.Д. Технология комбинированной структурированной рыбной массы на основе продуктов переработки сои // Науч. тр. Дальрыбвтуза. 2007. № 19. C. 257-265. 
6. Рензяева Т.В., Тубольцева А.С., Понкратова Е.К. и др. Функционально-технологические свойства порошкообразного сырья и пищевых добавок в производстве кондитерских изделий // Техника и технология пищевых производств. 2014. № 4. С. 43.

7. Субботина М.А. Исследование процесса поглощения влаги и растворимости кедровой муки // Техника и технология пищевых производств. 2009. № 3. С. 25-29.

\section{Literatura}

1. Doronin A.F., Demidova T.I., Shevernickaja O.N. idr. Funkcional'nye kombinirovannye poroshkovye produkty // Hranenie i pererabotka sel'hozsyr'ja. 2010. № 5. S. 45-48.

2. Spirichev V.B., Shatnjuk L.N., Poznjakovskij V.M. Obogashhenie pishhevyh produktov vitaminami i mineral'nymi veshhestvami. Nauka i tehnologii. Novosibirsk, 2004. $548 \mathrm{~s}$.

3. Skripko O.V., Litvinenko O.V., Pokotilo O.V. Obosnovanie tehnologii i ocenka kachestva soevogribnyh produktov dlja funkcional'nogo pitanija // Tehnika i tehnologija pishhevyh proizvodstv. 2016. № 3 (42). S. 77-83.

4. Skripko O.V., Litvinenko O.V., Pokotilo O.V. Razrabotka tehnologii funkcional'nyh produktov pitanija na osnove soi i paporotnika // Vestnik KrasGAU. 2017. № 6. S. 96-103.

5. Ol'hovaja L.P., Petrova L.D. Tehnologija kombinirovannoj strukturirovannoj rybnoj massy na osnove produktov pererabotki soi // Nauch. tr. Dal'rybvtuza. 2007. № 19. S.257-265.

6. Renzjaeva T.V., Tubol'ceva A.S., Ponkratova E.K. i dr. Funkcional'no-tehnologicheskie svojstva poroshkoobraznogo syr'ja i pishhevyh dobavok v proizvodstve konditerskih izdelij /I Tehnika i tehnologija pishhevyh proizvodstv. 2014. № 4. S. 43.

7. Subbotina M.A. Issledovanie processa pogloshhenija vlagi i ras-tvorimosti kedrovoj muki // Tehnika i tehnologija pishhevyh proizvodstv. 2009. № 3. S. 25-29. 